\title{
ALTERATION, VEIN TEXTURES AND FLUID INCLUSION PETROGRAPHY OF METAMORPHIC ROCK-HOSTED GOLD DEPOSIT AT ONZON- KANBANI AREA, CENTRAL MYANMAR: IMPLICATION FOR ITS GENESIS
}

\author{
Aung Tay Zar ${ }^{1,2}$, I Wayan Warmada ${ }^{1}$, Lucas Donny Setijadji ${ }^{1}$, and \\ Koichiro Watanabe ${ }^{3}$ \\ ${ }^{1}$ Department of Geological Engineering, Faculty of Engineering, Universitas Gadjah Mada, Yogyakarta, \\ Indonesia, e-mail: aungtayzar99@gmail.com \\ ${ }^{2}$ Geology Department, Pyay University, Pyay, Myanmar \\ ${ }^{3}$ Department of Earth Resources Engineering, Faculty of Engineering, Kyushu University, Fukuoka, Japan
}

Received Date: August 6, 2018; Revised Date: December 7, 2018; Acceptance Date: December 25, 2018

\begin{abstract}
Gold and base metal mineralization of Onzon-Kabani area is located at the western part of Mogok Metamorphic Belt in central Myanmar, where the well-known Sagaing Fault serves as its western boundary. Artisanal and small-scale gold operations started here three decades ago on gold mineralization hosted in marble and gneiss. Mineralization occurs as fracture-filling veins of several types: gold-bearing quartz vein, base metal quartz-carbonate vein, and carbonate base metal sulfides vein. Three types of hydrothermal alteration zones develop from the proximal to distal zone of hydrothermal conduit: silicic, sericite-illite and propylitic alteration. Alteration mineral assemblages consist of quartz, calcite, sericite, adularia, epidote, chlorite, illite and smectite which are typical of neutral $\mathrm{pH}$ hydrothermal fluid. The presence of adularia and calcite within veins indicate boiling event of near-neutral $\mathrm{pH}$ condition. Common vein textures of quartz and calcite are banded, crustiform, bladed calcite, lattice, mosaic or jigsaw, cockade, comb and zonal. Boiling-related mineral textures (e.g. banded, bladed and lattice) and fluid inclusion characteristics of coexisting liquid-rich and vapor-rich fluid inclusions have been identified in mineralized samples. Common ore minerals are pyrite, sphalerite, galena, chalcopyrite and minor marcasite, electrum and native gold. Gold is mostly associated with quartz gangue, pyrite, sphalerite and galena. Fluid-inclusion study suggests the presence of liquid-rich and vapor-rich fluid inclusions which were trapped in boiling fluid at homogenization temperature of 159 to $315^{\circ} \mathrm{C}$ and moderate salinity of 0.88 to 12.51 wt. $\% \mathrm{NaCl}$ equivalent. It is concluded that despite mesothermal gold system is more typical style of gold mineralization in the Mogok Metamorphic Belt, it is not the type of mineralization in the Onzon-Kanbani area. Instead, a low-sulfidation epithermal system is more characteristic to be present here. The knowledge generated from this study can serve as a guide in understanding new deposit type as well as mineral exploration in the region.
\end{abstract}

Keywords: Boiling, Fluid inclusion, Mogok metamorphic belt, Onzon-Kanbani, Vein textures

\section{Introduction}

The Onzon-Kanbani gold deposit is located within the Thabeikkyin Township, Mandalay Region, Central Myanmar. This area is a part of the Mogok Metamorphic Belt [1], which is one of Myanmar's major metallogenic provinces and prominent geological units (Figure 1). Generally, gold deposits within Mogok Metamorphic Belt (MMB) are considered as orogenic gold type [2], but other genetic types such as epithermal and skarn gold mineralization [3] are also present. In Onzon-Kanbani area, small-scale gold rush and abundant artisanal mining operations are in operation within last three decades. Gold and associated base metals 
mineralization are hosted in marble and less commonly in gneiss. Mineralized veins are mostly observed as fracture-filling veins and minor disseminated ore in marble. During the last decade, some geological investigations for regional geology and mineral exploration have been performed. However, mineralogical studies and understanding on the type of mineralization system are still lacking in this area. In the present study, we describe the mineralization characteristics within the Onzon-Kanbani area, based on hydrothermal alteration mineral assemblages, textural evidence especially on vein textures, and fluid inclusion petrography including microthermometric measurements, in order to classify the type of mineralization.

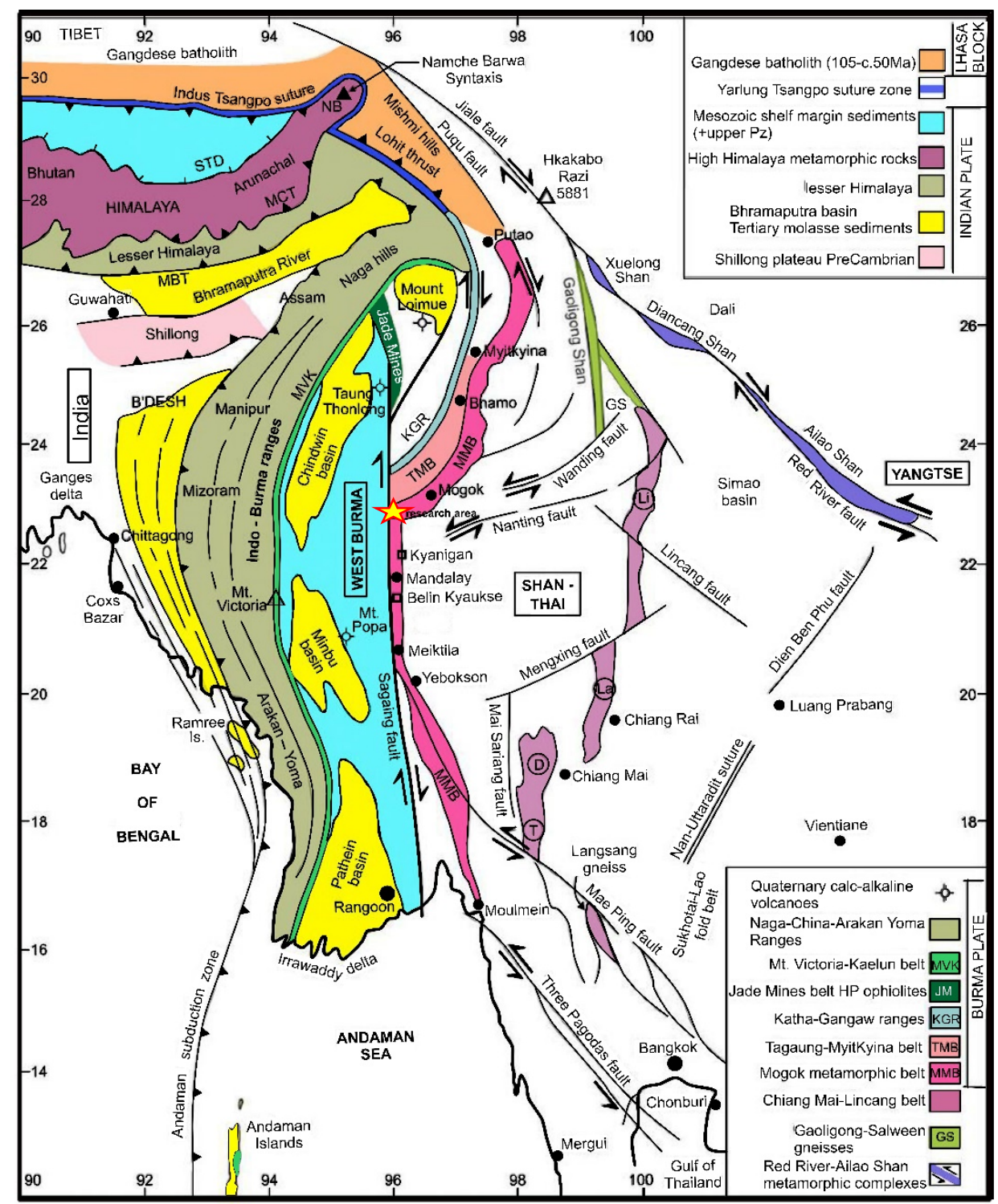

Figure 1. Regional geological map of Myanmar showing the principal tectonic units [4]. Research area is located within the Mogok Metamorphic Belt (MMB), marked by a star.

\section{Regional Geologic Setting}

The Mogok Metamorphic Belt (MMB) is one of the prominent geological units in Myanmar which trends generally N-S in direction with large-scale folding (Figure 1). It is located between West Burma (Central lowland) and Shan-Thai (Sibumasu) Block. The well-known Sagaing fault [5] serves as the western boundary of MMB. This belt is also the southern part of Himalayan syntaxis at the western margin of the Shan-Thai block and potentially links 
metamorphic and magmatic belts of Lhasa and Karakoram terranes in Tibet and Pakistan that directly faced the India collision [6]. Along the northeastern margin of India plate, the plate boundary shifted from Paleogene suture zone to Neogene Sagaing fault, while West Burma microplate has accommodated some of the northward motion of India [6]. Therefore, it has been suggested that Mogok Metamorphic Belt formed either by collision in the late Mesozoic [7] or by strike-slip movement in the Early Triassic [8]. This belt is mainly composed of pelitic gneisses, marbles, quartzite and calc-silicate rocks of Paleozoic to Mesozoic ages that were intruded by a variety of plutonic rocks such as biotite granite, syenite, leucogranite and minor pegmatite and aplite dikes of Eocene to Miocene ages. To the east, Shan Plateau is a topographic high with an average elevation of about $1,000 \mathrm{~m}$ and is mainly composed of carbonate and continental sedimentary rocks of Paleozoic-Mesozoic ages. The western margin of Mogok Metamorphic Belt is juxtaposed with central lowland which is filled with Eocene to Plio-Quaternary sediments.

\section{Methods of Study}

This research consists of field investigation and laboratory works. More than fifty (50) rock samples that consist of hydrothermally altered rocks, ore, and quartz vein samples were collected from field campaign. These samples were prepared as thin sections, double-polished thin sections, and polished sections in order to conduct several types of analysis. Thin sections and double-polish thin sections were examined petrographically to study primary and secondary (alteration) mineral assemblages. X-ray Diffraction (XRD) analysis was also performed for characterization of hydrothermal alteration and rock forming minerals, through clay-fraction and bulk-rock analysis in rock powder form. Several different treatments, such as ethylene glycol and hydrochloric acid $(\mathrm{HCl})$ treatments were performed to elucidate the specific types of clay minerals. Mineralization vein textures were carefully noted during the field observation, but some were interpreted in thin sections by optical microscopy using transmitted light. Alternatively, ore polished sections were observed using reflected light under microscopic study to study ore mineral assemblages and textural relationships. Furthermore, some of the ore minerals were confirmed again by scanning electron microscopy with energydispersive X-ray (SEM-EDX). Fluid inclusion analysis was performed on double polished quartz wafers of varied thickness between 150 and 300 $\mu \mathrm{m}$. In total, seven (7) quartz veins samples were collected from mineralization veins. Sample selection was done based on quartz textures and abundance of ore minerals. To confirm the characteristics of fluid inclusions, petrographic observation was firstly performed in order to select representative samples for microthermometric measurements. Measurements were conducted using a Linkam THMSG600 that combines heating and freezing stage and is attached to a Nikon petrographic microscope with Axiovision software. All laboratory analyses were done at the Department of Earth Resource Engineering, Mineral Resource lab, Kyushu University, Japan.

\section{Geology of Onzon-Kanbani Area}

In the Onzon-Kanbani area, exposed rocks are dominated by metamorphic and igneous rocks (Figure 2). Metamorphic rocks include a variety of marbles, calc-silicate rocks, and gneiss, which are widely distributed in research area. The geologic age of the protoliths of metamorphic rocks was originally considered as Precambrian [9], but the presence of Permian fossils in marbles near Kyaukse [10] indicates that Carboniferous to Triassic ages are more likely. Metamorphic rocks are intruded by granite, leucogranite, and syenite. Stratigraphically, gneiss is the oldest rock unit in the research area, where it is widely observed in eastern part as biotite gneiss and minor garnet-biotite gneiss. The gneiss unit is unconformably underlain by marble unit which is the dominant rock type in research area. Marbles are classified according 
to the mineral contents into diopside marble, phlogopite marble, and pure white marble. In places, calc-silicate rock is interbedded within diopside marble along the margin of igneous intrusions. Igneous units are found in the middle part of research area as several isolated outcrops. The main type of igneous intrusion bodies is biotite microgranite, also known as "Kabaing granite”. Other bodies are smaller leucogranite and syenite intrusive bodies. Barley et al., [6] described the ages of magmatism within the Mogok Metamorphic Belt, in which they concluded that leucogranite and syenite melts were emplaced during the Eocene time contemporaneous with the regional metamorphism. Meanwhile, Kabaing granite intruded to the country rocks in the Miocene [11] after the period regional metamorphism by the process of faulting and overthrusting.

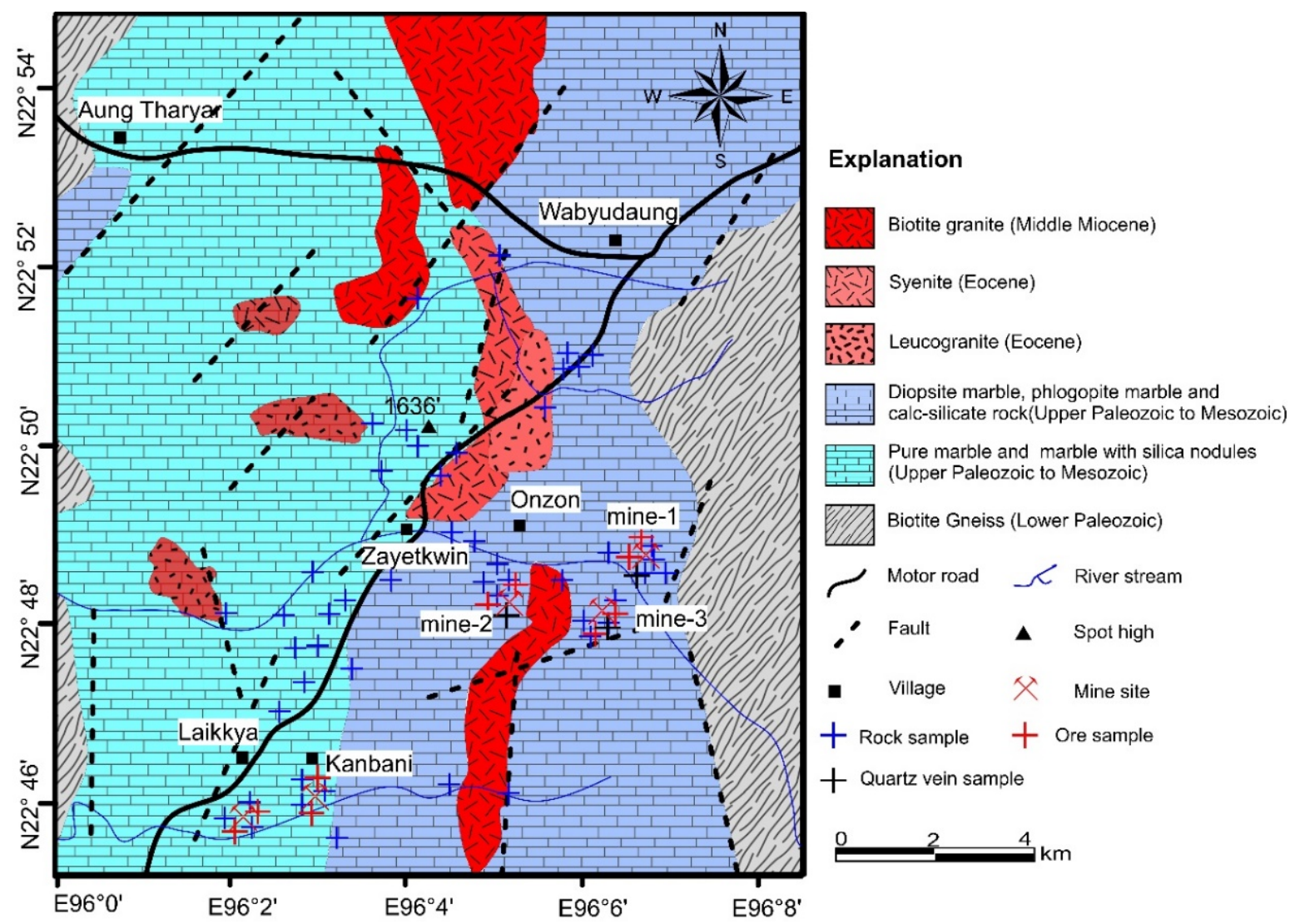

Figure 2. Simplified geological map of the Onzon-Kanbani area, and locations of gold mine sites and collected samples. Map is modified after Thein et al. [12]

\section{Gold Mineralization and Vein Textures}

Gold mineralization in the research area is mainly hosted in marble and occasionally in gneiss. It is mostly observed as fracture-filling veins, and in lesser amount as disseminated ore within the marble. Mineralization veins occur as (1) gold-bearing quartz vein (Figure 3), (2) base metal quartz-carbonate vein (Figure 4a) and (3) carbonate base metal sulfides vein (Figure 4b). These veins occupy fractures and shear zones which are trending N-S, NE-SW, and NW-SE with steep dipping of about $55^{\circ}$ to nearly vertical. These structural trends might be controlled by the movement of Sagaing fault system. Many gold worksites operate on narrow mineralization zones where the width of mineralized veins are generally 0.5 to 5 meters. Goldbearing quartz veins and base metal quartz-carbonate veins are mainly observed in the eastern 
part of the research area (near Onzon city) whereas carbonate base metal sulfides veins are dominantly observed in the southern part (near Kanbani city) of the research area.

A variety of vein textures are observed in mineralization veins, such as massive quartz, banded quartz, lattice, bladed, mosaic, comb, cockade and zonal (Figures 5 \& 6). The banded or crustiform texture is the primary texture of mineralized vein and is mainly observed in gold-bearing quartz vein and base metal quartz-carbonate vein. In addition, some bands contain subordinate adularia with its typical rhombic shape. Lattice and bladed calcite which has been replaced by quartz are also common textures in the mineralization veins. Mostly, bladed calcite observed abundantly along the vein boundary of the base metal quartz-carbonate vein. According to field observation and information from local gold miners, bladed calcite and quartz textures are pathfinder textures that are closely associated with gold. Simmons and Christenson [13] described the close association between bladed (platy) calcite and boiling in geothermal systems and attribute this morphology to the rapid growth of calcite as carbon dioxide is lost to the vapor phase during boiling. Zonal, comb, and cockade textures are also frequently observed. In comb and cockade textures, parallel quartz crystals are oriented perpendicular to the mineralized vein wall (Figures $5 \& 6$ ).
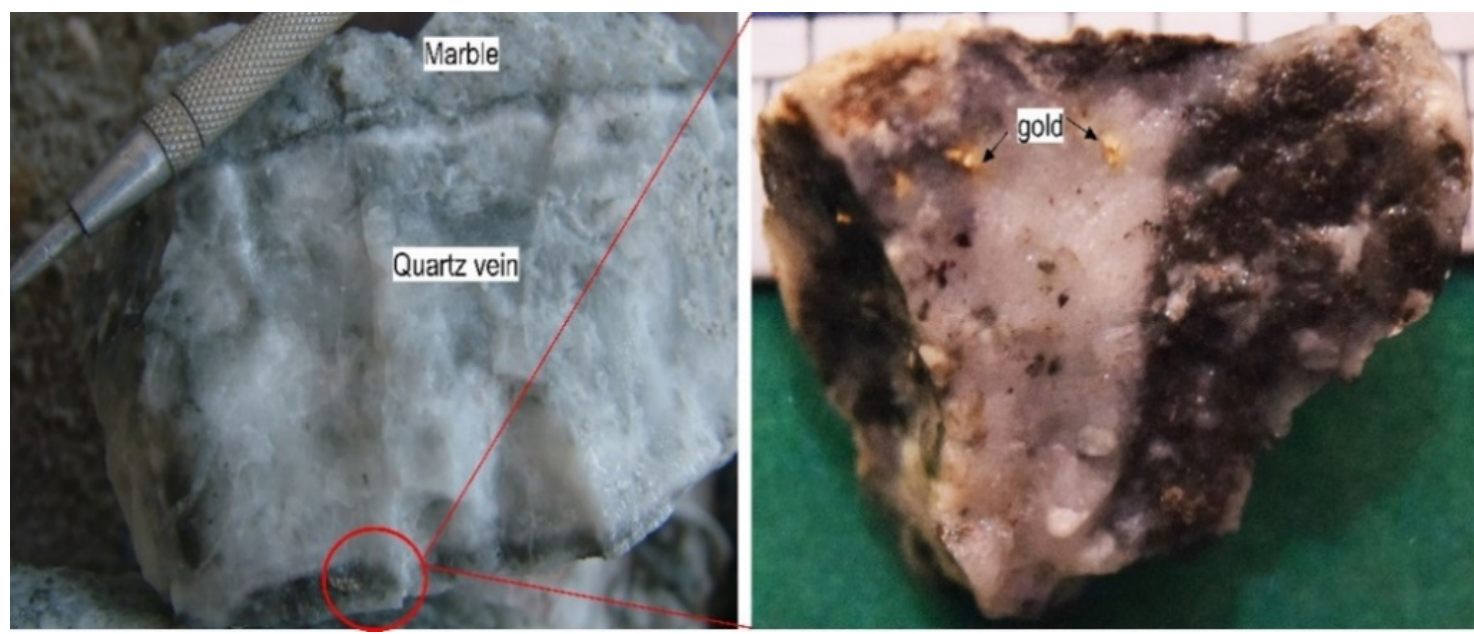

Figure 3. Gold-bearing quartz vein hosted within marble
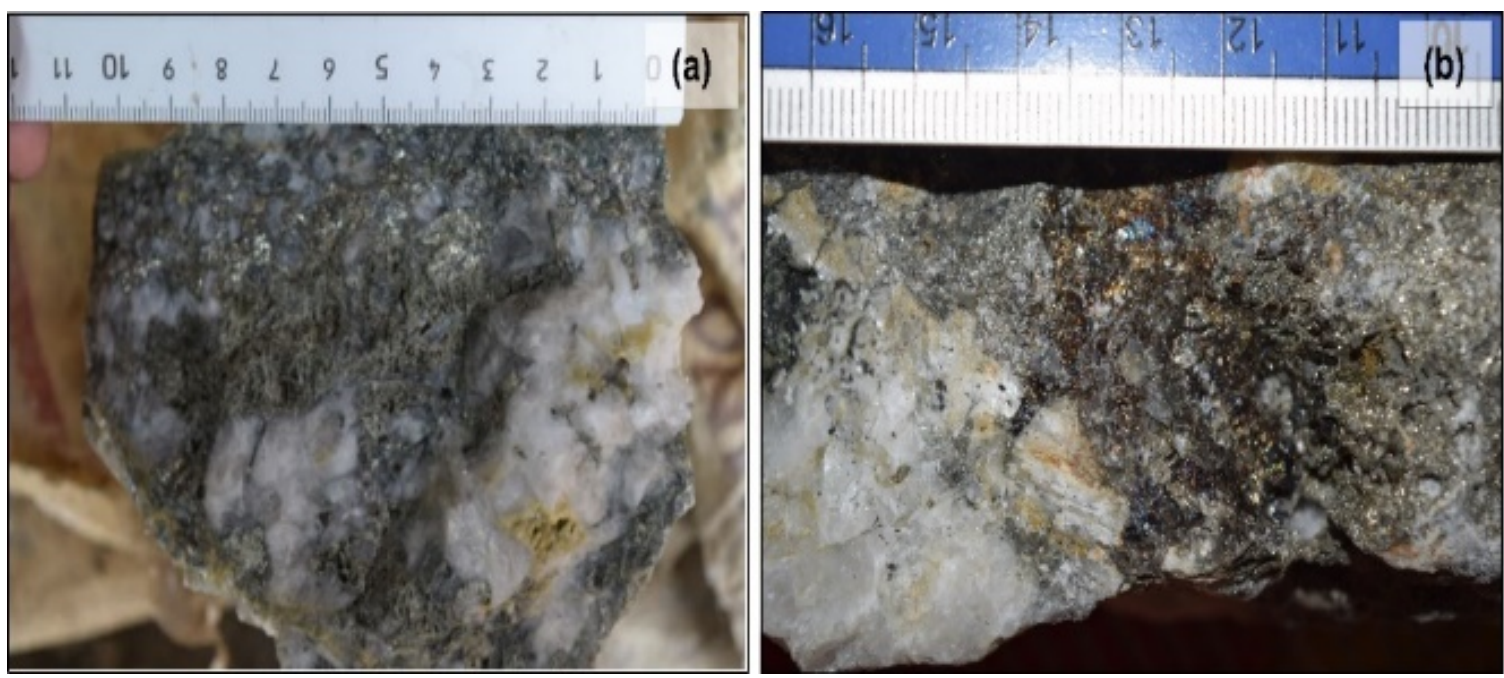

Figure 4. (a) Base metal quartz-carbonate vein and (b) Carbonate base metal sulfides vein 

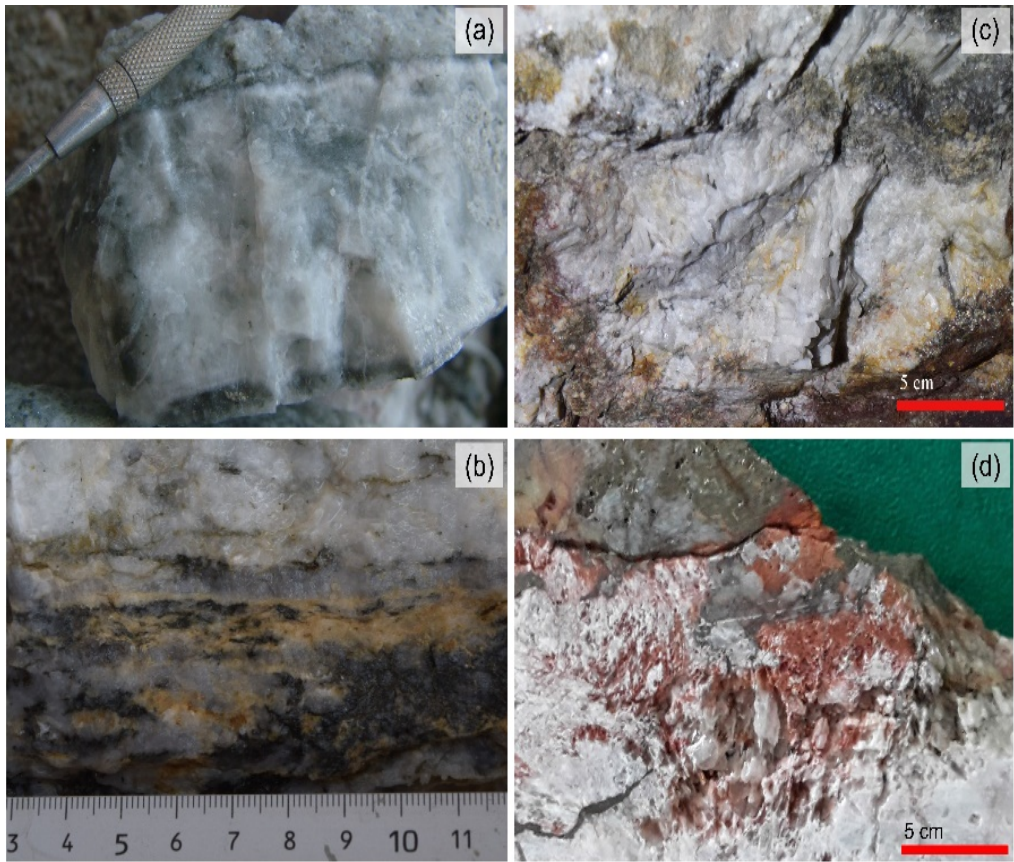

(d)

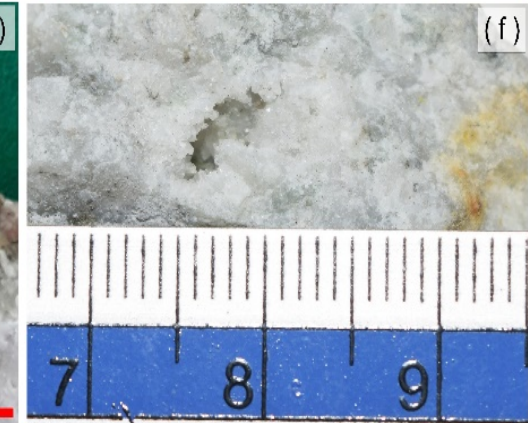

Figure 5. Characteristic vein textures: (a \& b) Massive and banded quartz, (c \& d) Lattice texture calcite and platy calcite, (e) Comb texture quartz, and (f) Cockade texture quartz vein
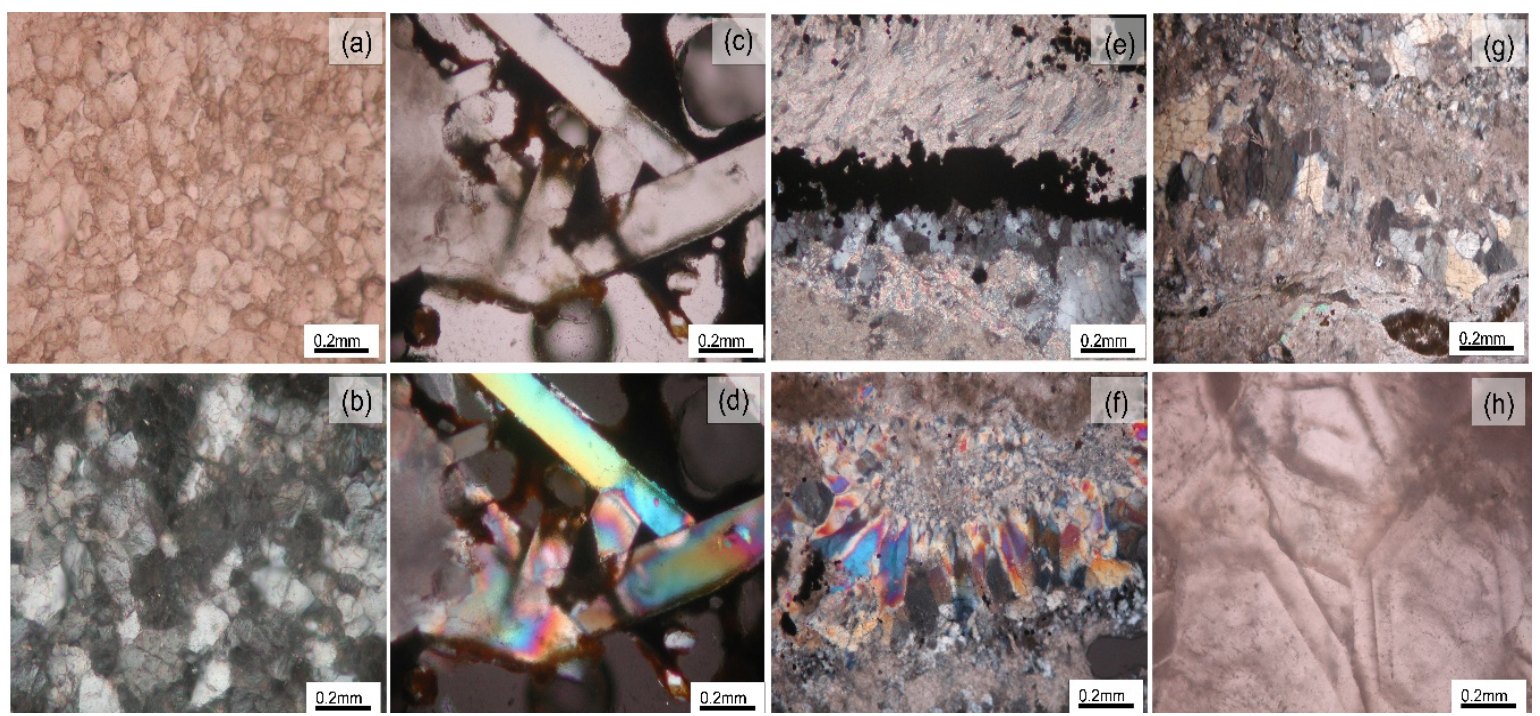

Figure 6. Photomicrographs of mineral textures: (a \& b) Mosaic or jigsaw texture with crystalline quartz grains, (c \& d) ghost bladed quartz texture in plane and crossed polar light, (e) quartz and pyrite bands of crustiform texture, (f) cockade texture quartz under crossed polar light, and (g) comb texture in quartz vein and (h) zonal texture in euhedral quartz grains

The common primary ore minerals in mineralization veins are pyrite, sphalerite, galena, chalcopyrite and minor marcasite, arsenopyrite, native gold, and electrum. On the other hand, chalcocite, covellite, hematite, and goethite occur as late supergene minerals reflecting the oxidation of primary sulfides. The generalized paragenetic sequence of Onzon-Kanbani ore 
system is shown in Table 1. Pyrite is the most abundant sulfide mineral in the ore body, formed over the entire period of mineralization as fine-grained massive aggregates to large euhedral grains. Gold occurs as free grains or locked within pyrite, sphalerite, galena, and gangue mineral quartz. There are two types of gold, 'native gold' and 'electrum' based on their atomic percentage of Au. In gold-bearing quartz vein, electrum gold is observed as large grains associated with quartz gangue, pyrite, and sphalerite (Figure 7a \& 7c). Alternatively, native gold occurs as fine grains in the base metal quartz-carbonate vein and carbonate base metal sulfides vein. Native gold is observed as micrometric blebs and specks in pyrite, sphalerite, and galena (Figure 7b \& 7d). Generally, native gold is high in Au content at $80-87 \%$ and small in size $(25-100 \mu \mathrm{m})$, whereas electrum is less than $80 \%$ Au with larger size between $100-200$ $\mu \mathrm{m}$ (Figure 8).

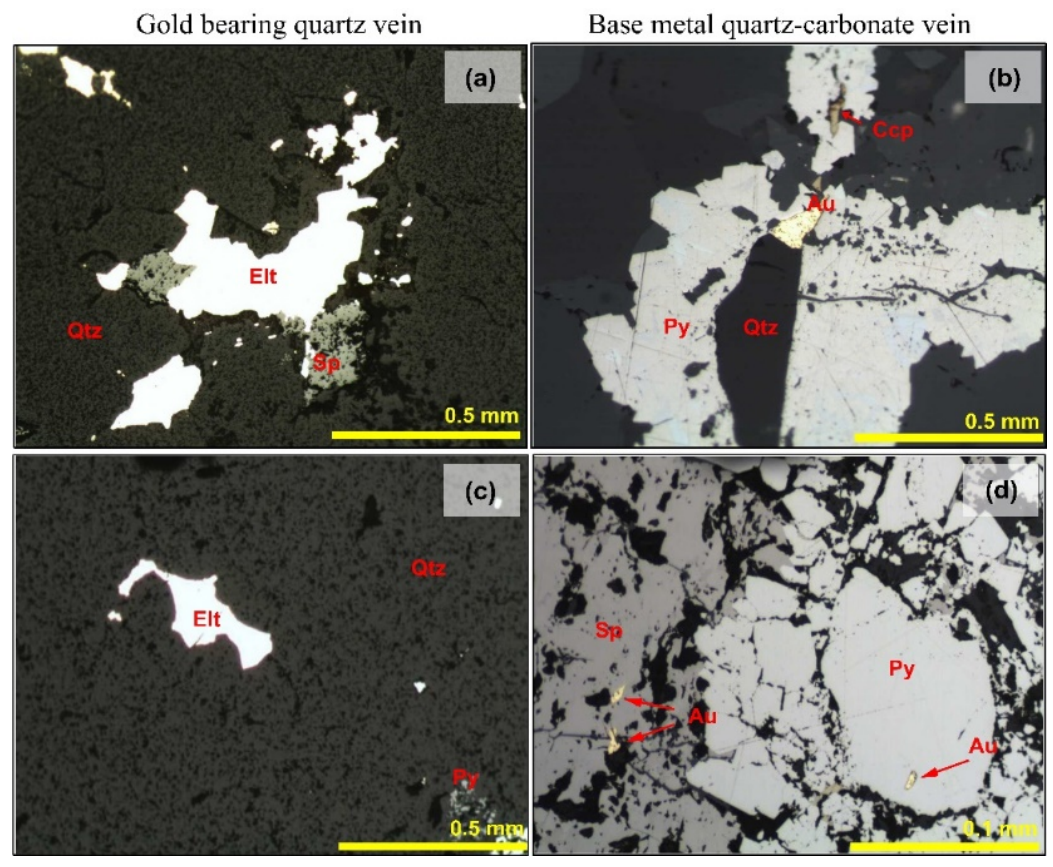

Figure 7. (a and c) Photomicrographs showing large grains of electrum (Elt) associated with sphalerite ( $\mathrm{Sp}$ ) in quartz vein; (b and d) small native gold ( $\mathrm{Au}$ ) grains within pyrite (Py) and sphalerite (Sp) in base metal quartz-carbonate vein

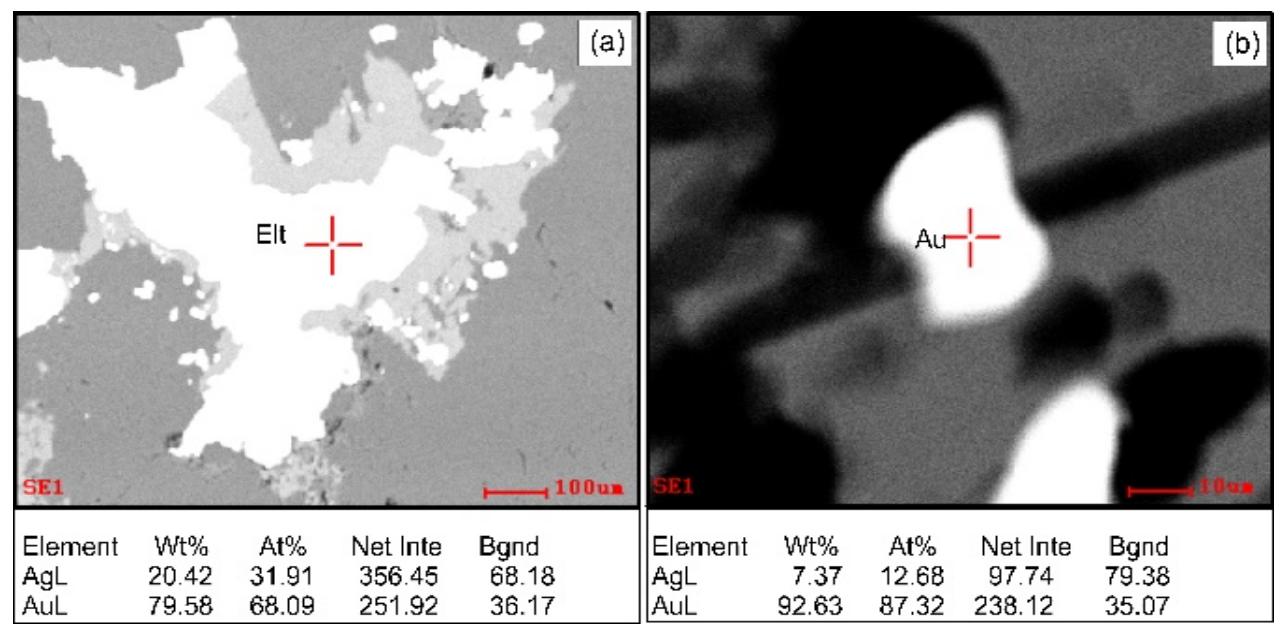

Figure 8. Back scattered images of electrum and native gold grains with elemental compositions 
Table 1. Generalized Paragenetic Sequence of Mineralization at Onzon-Kanbani Area

\begin{tabular}{|c|c|c|c|c|}
\hline \multirow{2}{*}{ Minerals } & \multicolumn{2}{|c|}{ Stage-1 (Mineralization) } & \multirow{2}{*}{$\begin{array}{c}\text { Stage-2 } \\
\text { (Barren) }\end{array}$} & \multirow{2}{*}{$\begin{array}{c}\text { Oxidation } \\
\text { stage }\end{array}$} \\
\hline & Phase-1 & Phase-2 & & \\
\hline \multicolumn{5}{|l|}{ Quartz } \\
\hline Adularia & & --- & & \\
\hline Sericite & & & & \\
\hline Calcite & & & & \\
\hline Illite & & & & \\
\hline Pyrite & & & --- & \\
\hline Arsenopyrito & & & & \\
\hline Sphalerite & & & & \\
\hline Galena & & & & \\
\hline Chalcopyrite & & & & \\
\hline Electrum & & & & \\
\hline Native Gold & & & & \\
\hline Marcasite & & & & \\
\hline Chalcocite & & & & \\
\hline Covellite & & & & - \\
\hline Hematite & & & & \\
\hline Goethite & & & & 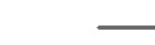 \\
\hline
\end{tabular}

\section{Wall-Rock Alteration}

Mineralization-related hydrothermal alteration is observed in the marble wall-rock unit. Alteration developed around fracture-filling mineralized vein at fractures and shear zones. In general, hydrothermal alteration zones are narrow and they overlapped regional metamorphism that occurred in the study area. There are three types of hydrothermal alteration found, and from the proximal to distal zone of hydrothermal conduits they consist of (1) silicification, (2) sericite-illite and (3) propylitic alteration (Figure 9). Locally, chloritization is also observed. Normally hydrothermal alteration zonation is difficult to recognize in outcrops because of the intensity of weathering and thick soil cover. Alteration zones are better recognized in underground mines especially in the eastern part of the research area (Onzon area). The alteration zones have been identified through field observation of altered rock samples, and later are confirmed by thin section and XRD analysis on collected samples. The common hydrothermal minerals from different zones are quartz, calcite, adularia, sericite, illite, smectite, chlorite and epidote.

\section{Silicic Alteration}

From petrographic observation of thin sections, the silicic alteration zone is characterized by an abundance of quartz, calcite, and illite with chlorite and adularia are also frequently observed. The XRD diffractograms also confirmed that quartz, calcite, illite, and pyrite are the dominant minerals. Silicic alteration is overlapped with mineralization vein, where the rock matric is strongly silicified. Adularia is found within quartz vein with a rhombic shape and irregular extinction pattern under cross polarized light (Figure 10). Chalcedony and amorphous silica occurr locally along the fractures that indicate the rapid deposition during alteration. Mineralization veins from this zone display banded, crustiform, comb, cockade and some vuggy textures. Sometimes, this altered zone attains yellow or rusty color because of oxidation of sulfide minerals that have taken place until considerable depth. 

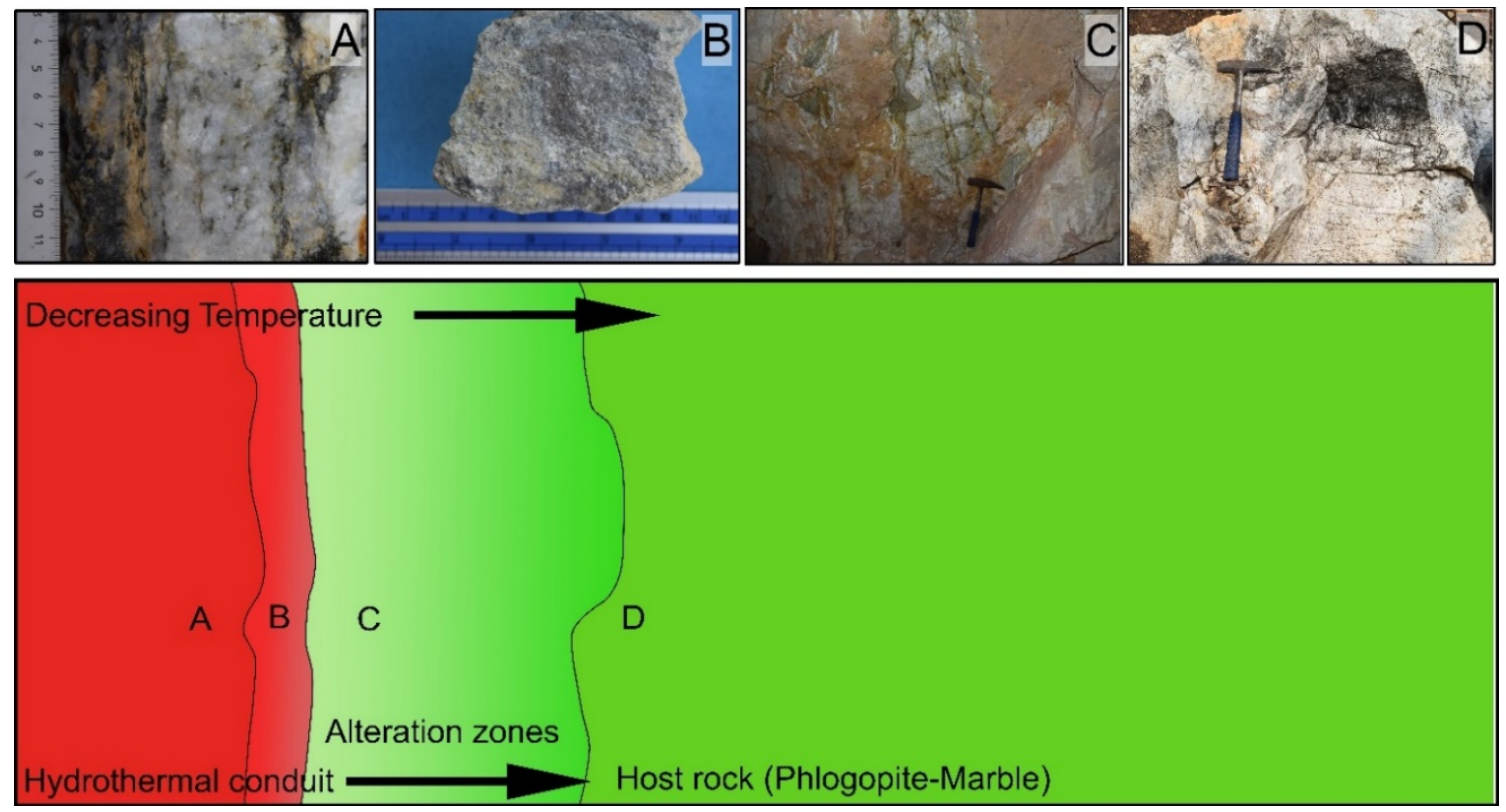

Figure 9. Hydrothermal alteration at Onzon-Kabani area from proximal to distal zones of hydrothermal conduit. Zone boundaries are determined based on mineral assemblages. Zone symbols: A. hydrothermal conduit/silicic alteration, B. sericiteillite alteration, C. propylitic alteration, D. host rock)

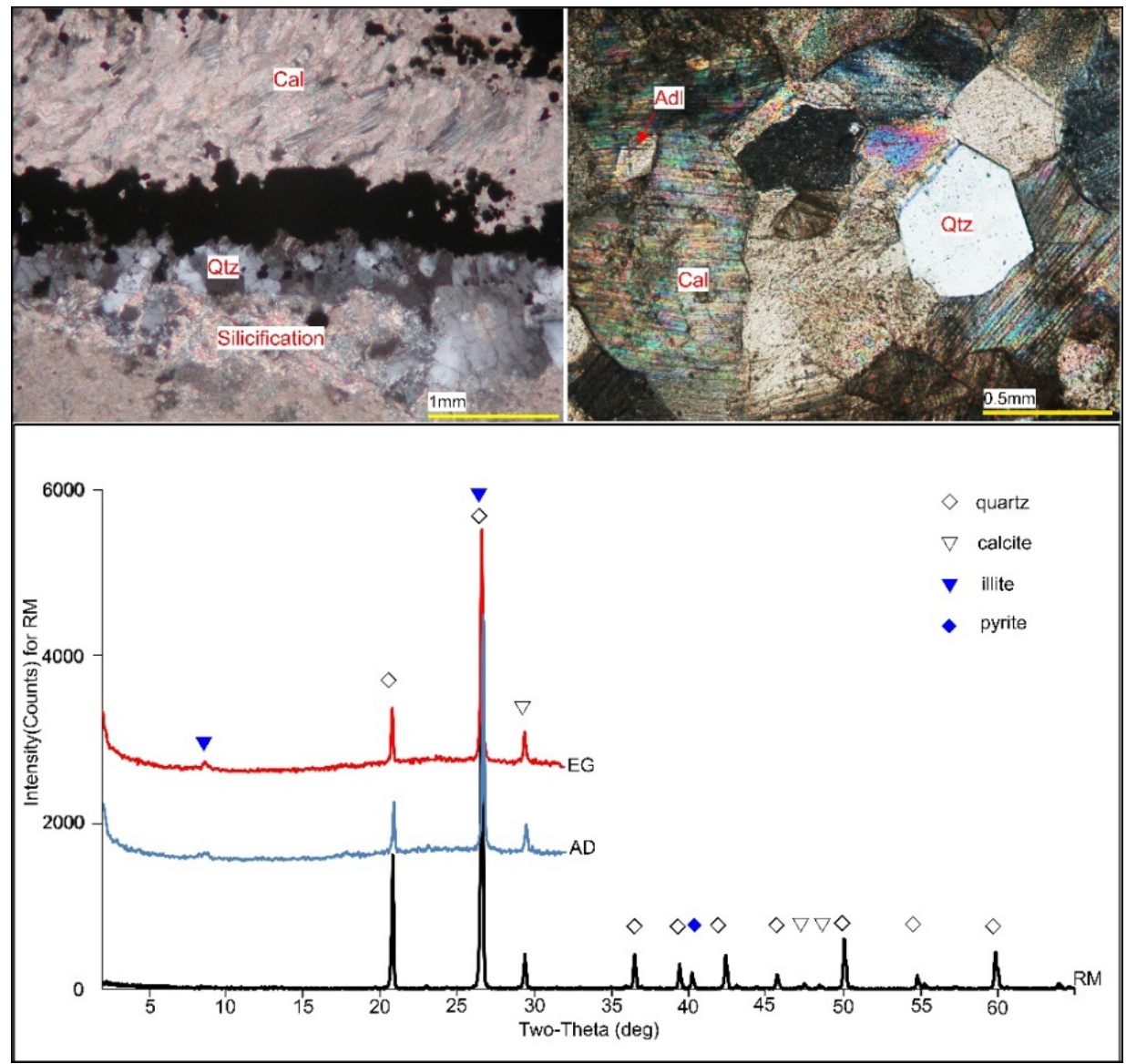

Figure 10. Petrographic images of silicic alteration sample and its X-ray diffractogram (Qtz=quartz, Cal=calcite, $\mathrm{Adl}=$ adularia, $\mathrm{RM}=$ random mount, $\mathrm{AD}=$ air-dried and $\mathrm{EG}=$ ethylene glycolated) 


\section{Sericite-Illite Alteration}

This alteration zone is only narrowly formed outside the silicic alteration zone and mineralized vein, and sometimes it is not even recognized. From the petrographic study and XRD analysis, this alteration zone is composed of quartz, muscovite (sericite), calcite and minor chlorite. Sericite occurs as widespread fine-grained aggregates (Figure 11).

\section{Propylitic Alteration}

The propylitic alteration is the outermost zone of the alteration halos, next to the sericite-illite zone. This zone is widely distributed and is composed of calcite, quartz, chlorite, illite, smectite, epidote, and pyrite. Propylitic alteration zone generally preserves some of the primary textures of the host rock. Key minerals of propylitic alteration zones are chlorite and epidote, which are mostly observed from petrographic study (Figure 12). X-ray diffractograms show the peaks of chlorite, calcite, quartz, illite and smectite. Some parts of propylitic alteration had formed prior to the ore deposition and might be genetically unrelated to the ore-forming hydrothermal process [14].

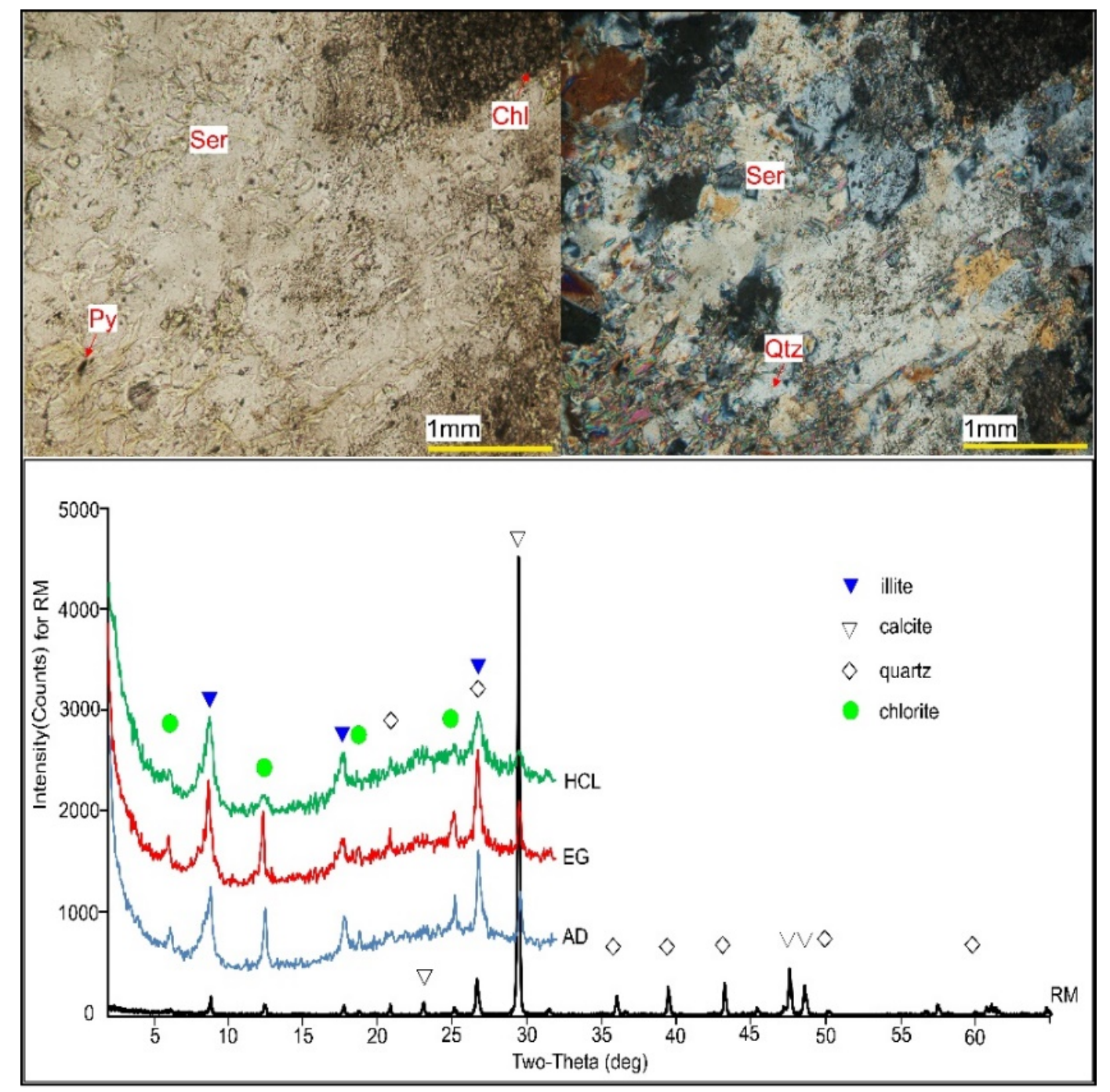

Figure 11. Petrographic images of sericite-illite alteration sample and its X-ray diffractogram (Qtz=quartz, Ser=sericite, Chl=chlorite, $\mathrm{Py}=$ =pyrite, $\mathrm{RM}=$ random mount, $\mathrm{AD}=$ =airdried, EG=ethylene glycolated and $\mathrm{HCl}=$ hydrochloric acid) 

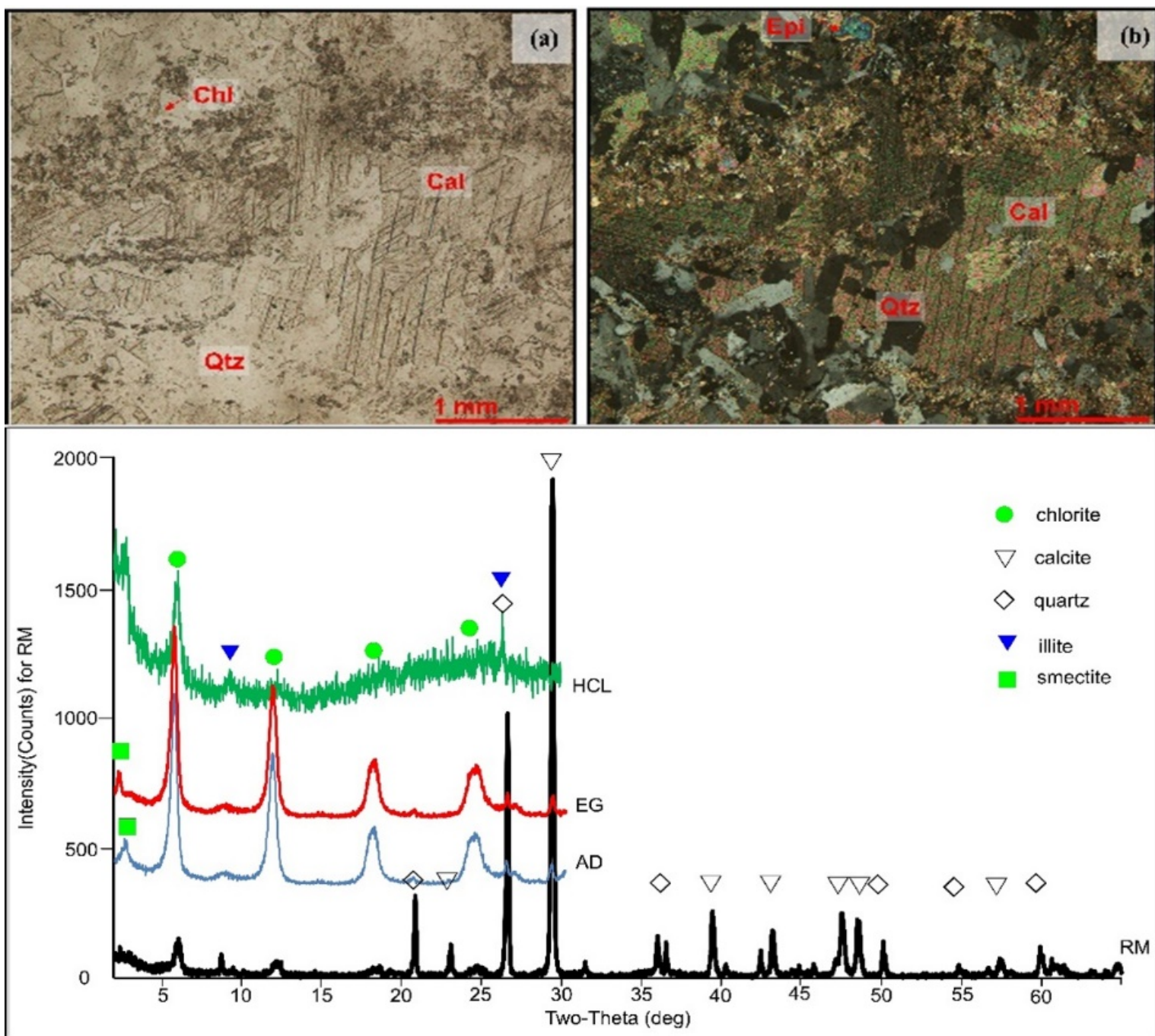

Figure 12. Petrographic images of propylitic alteration sample and its X-ray diffractogram (Cal=calcite, $\mathrm{Chl}=$ chlorite, Epi=epidote, $\mathrm{RM}=$ random mount, $\mathrm{AD}=$ =air-dried, $\mathrm{EG}=$ ethylene glycolated and $\mathrm{HCl}=$ hydrochloric acid)

\section{Fluid Inclusion Study}

\section{Fluid Inclusion Petrography}

Mineralized quartz vein samples are taken from three local gold mines (i.e. Mine-1 to 3). In total ten double polished quartz wafers were prepared for petrographic observations, from which seven samples were selected for microthermometric measurements. The quartz samples are generally rich in primary inclusions trapped during precipitation of the host phase and some are trail-bound secondary inclusions. These fluid inclusions are mostly negative crystals, rounded, elongated to irregular in shapes that are typically ranging from 5 to $50 \mu \mathrm{m}$ in size. They are generally two-phase inclusions at room temperature with variable liquid and vapor proportions at $10-90 \%$ of total inclusion volume.

Fluid inclusion assemblages in Onzon-Kanbani area can be further divided as (1) two-phase liquid-rich inclusions with the constant liquid-to-vapor ratio, (2) two-phase liquid and vapor containing coexisting liquid-rich and vapor-rich inclusions with a broad range of liquid to vapor ratios, and (3) two-phase vapor-rich inclusions (Figure 13). 


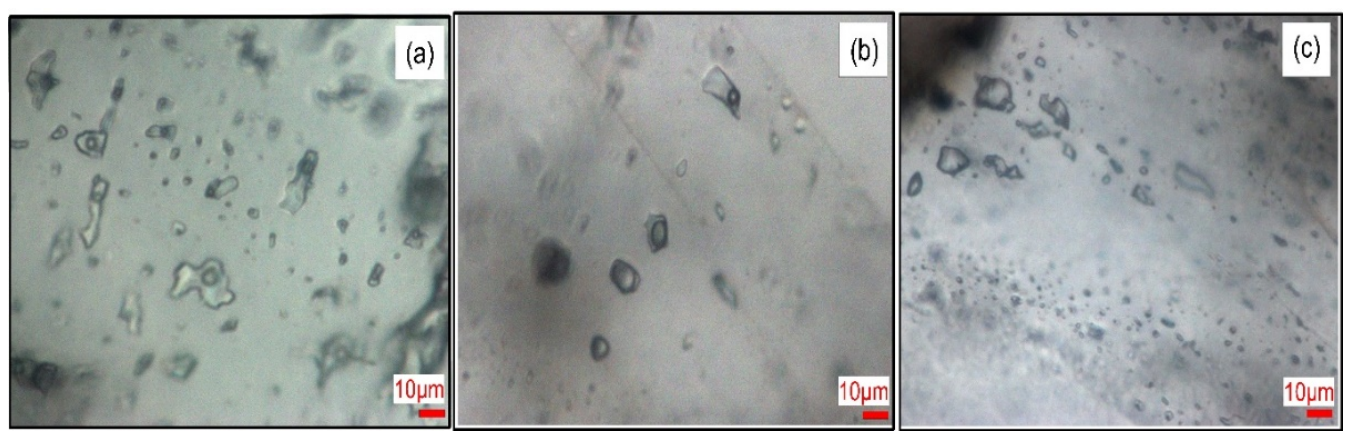

Figure 13. Fluid inclusion types observed in samples from Onzon-Kanbani area, (a) liquidrich inclusions with consistent liquid-to-vapor ratio, indicative of non-boiling, (b)

coexisting liquid-rich and vapor-rich fluid inclusions, indicative of boiling condition, and (c) vapor-rich inclusions only that indicate flashing of the system.

\section{Fluid Inclusion Microthermometry}

Fluid inclusion microthermometric data were collected from selected seven samples of mineralized quartz wafers. The common two-phase liquid rich fluid inclusions were analyzed for microthermometric measurements. These liquid rich two-phase inclusions are expected to be primary fluid inclusions and they are also reliable to measure (i.e. size $>5 \mu \mathrm{m}$ ). Vapor-rich inclusions were not analyzed because of the difficulty in visual estimation of homogenization temperature and ice melting temperature. Homogenization temperature $\left(T_{h}\right)$ and ice melting temperature ( $\mathrm{Tm}$ ) were measured for 103 fluid inclusions from all samples collected from three mine sites. Salinities were calculated using Bodnar's equation using the ice melting temperature $\left(T_{m}\right)$ [15]. The homogenization temperatures $\left(T_{h}\right)$ of fluid inclusions range between $159^{\circ} \mathrm{C}$ to $315^{\circ} \mathrm{C}$ where ice melting temperatures $\left(T_{m}\right)$ vary between -0.5 to $-8.7^{\circ} \mathrm{C}$. The salinity of fluid inclusions ranges between 0.88 to $12.51 \mathrm{wt}$ \% $\mathrm{NaCl}$ equivalent. The values of $\mathrm{Th}$ and salinity of the analyzed samples are summarized in histograms (Figure 14)

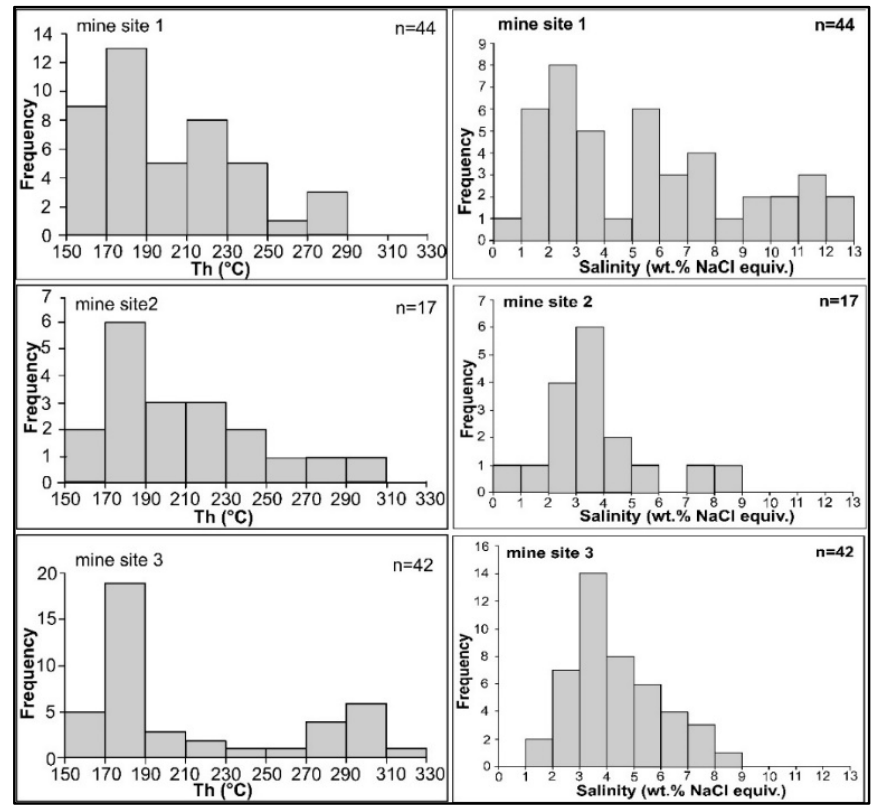

Figure 14. Microthermometric data for primary fluid inclusions in quartz veins from Onzon-Kabani area. Left figures show frequency distribution of homogenization temperature data $\left(T_{h}\right)$, and right figures for salinity data. ( $\mathrm{n}=$ number of analyzed fluid inclusions) 


\section{Interpretation of Fluid Inclusion Data}

Bodnar et al., [15] stated that if the inclusions are trapped in a boiling or immiscible fluid system, the fluid inclusions will be found in the liquid phase, the vapor, and in mixtures of the two phases. In the petrographic examination, the phase relations of individual inclusions were examined where the fluid inclusion assemblages revealed variable ratios or same liquid to vapor ratio. Consistent phase ratios of liquid and vapor are indicative for condition of temperature and pressure in a non-boiling condition. On the other hand, variable phase ratios (or) coexisting liquid-rich and vapor-rich inclusions indicate that the fluid inclusions were trapped in boiling condition. Variable liquid to vapor ratios of necking down fluid inclusions resulted after a vapor bubble has nucleated in the inclusion. Furthermore, the presence of vapor-rich fluid inclusions assemblage indicates the intense boiling or flashing condition [16]. It is suggested that mineralization fluid of Onzon-Kanbani has taken place in boiling condition.

Moreover, moderate to low salinity (0.88-12.51 wt\% $\mathrm{NaCl}$ equiv.) of liquid-rich inclusions show a variation of salinity. This variation pointed out boiling or effervescence in the system, but significant salinity increase will only take place by continuous boiling in the restricted fractures [17]. Fluid inclusions trapped under boiling condition or immiscibility is a very useful indicator to suggest $\mathrm{P}$-T condition because the homogenization temperature equals the formation temperature [18]. The plot diagram of microthermometric data 'Th-salinity diagram' shows that fluid inclusions data of Onzon-Kanbani area are located on the territory of epithermal environment (Figure 15). A general increase in homogenization temperature $\left(T_{h}\right)$ at low salinity is observed in measurement.

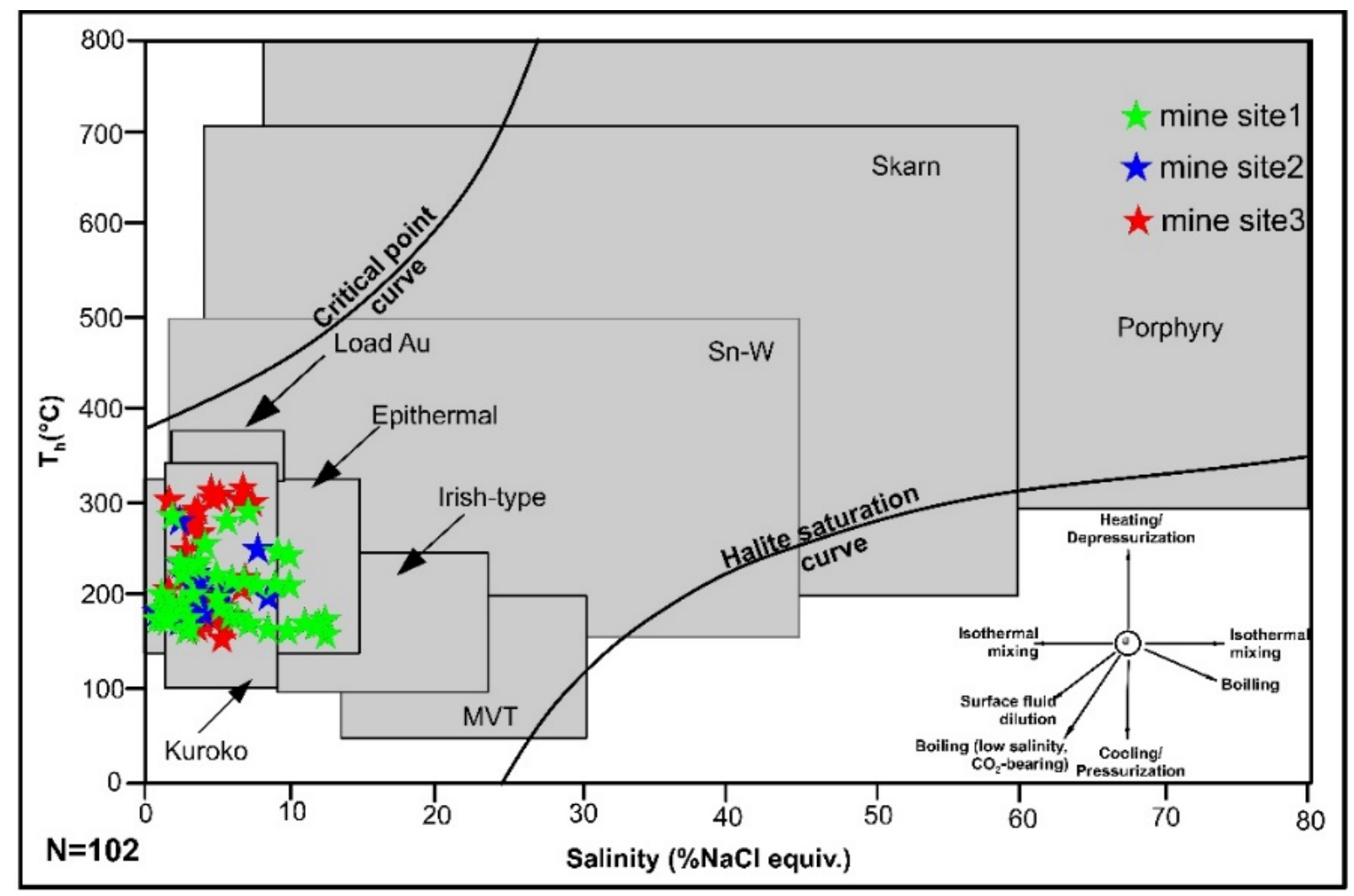

Figure 15 (a). $T_{h}\left({ }^{\circ} \mathrm{C}\right)$-salinity diagram illustrating typical ranges for inclusions from different deposit types [17]. 

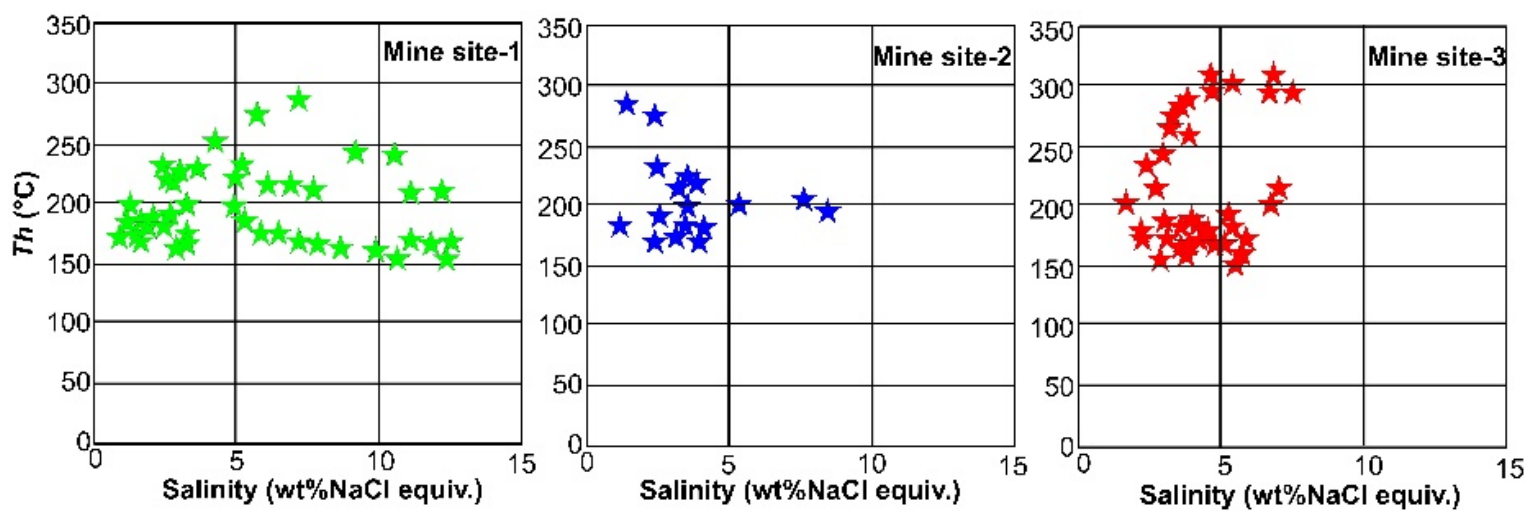

Figure 15 (b). $T_{h}\left({ }^{\circ} \mathrm{C}\right)$-salinity diagram. Color stars are data from the Onzon-Kanbani gold deposit.

\section{Concluding Discussion}

The Onzon-Kanbani gold deposit holds several distinct features that have been commonly found in low-sulfidation epithermal system. Gold and base metal mineralization is generally observed as fracture-filling veins that crosscut the host rocks of marble and gneiss. The age of mineralization is reasonably younger than the Eocene to Late Oligocene time of metamorphism in the Mogok Metamorphic Belt [4], [6]. Veins formation is probably associated with the movements of Sagaing fault during the Late Miocene [19] that produced N-S, NE-SW, and NW-SE fracture zones. The hydrothermal system is regarded to be low-sulfidation epithermal style through the characteristics of alteration halos and mineral assemblages. Wall-rock alterations consist of silicic, illite-sericite and propylitic alterations halos from the proximal to distal zone of the hydrothermal conduit. It indicates that alteration intensity reduced away from the hydrothermal conduit. Moreover, alteration mineral assemblages of quartz, calcite, sericite, adularia, epidote, chlorite, illite and smectite are typical of neutral $\mathrm{pH}$ condition of hydrothermal fluid. Both adularia and calcite indicate near-neutral $\mathrm{pH}$ conditions [20] that they are also common gangues of low-sulfidation epithermal system. Mineralization veins are observed as fracture-filling at fracture and shear zones. Common ore minerals in OnzonKanbani area are pyrite, sphalerite, galena, chalcopyrite and minor marcasite, electrum and native gold. Gold is mostly associated with quartz gangue and base metal pyrite, sphalerite and galena. This ore mineral assemblage is common in low-sulfidation epithermal system. Furthermore, vein textures and fluid inclusion petrography including microthermometric measurements have pointed some characteristics of epithermal deposit. A variety of vein textures are observed in mineralization veins where some are diagnostic textures that identify the physio-chemical conditions of hydrothermal fluid associated with mineralization [21]. Lattice, bladed and banded/crustiform textures indicated boiling fluids of near neutral to alkaline $\mathrm{pH}$ condition [22], [23]. They might have formed as a result of rapid precipitation from the hydrothermal fluid, as a result of boiling. In addition, cooling and increasing of $\mathrm{pH}$ may lead to the formation of banded/crustiform bands of ore and gangue minerals. Other processes such as fluid mixing also seems to be effective on such a precipitation. Gold mineralization is associated with boiling textures such as bladed and banded. It is therefore concluded that boiling is an important depositional mechanism for ore mineralization. Boiling around ore zone causes loss of $\mathrm{CO}_{2}$ and $\mathrm{H}_{2} \mathrm{~S}$ and a consequent increase in $\mathrm{pH}$ [22]. This process is in favor to precipitate ore and gangue minerals (e.g. calcite and adularia). In fluid-inclusion petrography, the presence of coexisting liquid-rich and vapor-rich fluid inclusions indicates that the inclusions were trapped in boiling fluid. The microthermometric results of homogenization temperature of 159 to $315^{\circ} \mathrm{C}$ and moderate salinity of 0.88 to $12.51 \mathrm{wt} \% \mathrm{NaCl}$ equivalent are reliable to conclude that mineralization occurred under epithermal condition. Based on the 
results of this study, the Onzon-Kanbani gold deposit is interpreted to be formed by near neutralized, high $\mathrm{pH}$ hydrothermal fluid where boiling, cooling and mixing were responsible for the gold deposition. However, the source of the fluid, either it was magmatic or meteoric origin, could not be equivocally determined from the available data.

\section{Acknowledgement}

This research is funded by the AUN/SEED-Net (JICA program). We would like to thank all local companies and mining owners for their permission to conduct research work there and their kind supports during field investigation.

\section{References}

[1] D.L. Searle, and B.T. Haq, "The Mogok Belt of Burma and Its Relationship to the Himalayan Orogeny,” In: Proceedings of the International Geological Congress, Vol. 22, pp. 132-161, 1964.

[2] A.H.G. Mitchell, C.A. Ausa, L. Deiparine, T. Hlaing, N. Htay, and A. Khine, "The Modi Taung - Nankwe gold district, Slate belt, central Myanmar: Mesothermal veins in a Mesozoic orogen,” Journal of Asian Earth Science, Vol. 23, No. 3, pp. 321-341, 2004.

[3] T.A. Myint, T.N. Than, and A. Min, "Precious and Base Metal Mineralization in Kwinthonze-Nweyon area, Singu and Thabeikkyin Townships, Mandalay Region, Myanmar,” Proceedings of Sundaland Resources 2014 MGEI Annual Convention, pp. 343-354, 2014.

[4] M.P. Searle, S.R. Noble, J.M. Cottle, D.J. Waters, A.H.G. Mitchell, T. Hlaing, and M.S. A. Horstwood, "Tectonic evolution of the Mogok metamorphic belt, Burma (Myanmar) constrained by U-Th-Pb dating of metamorphic and magmatic rocks,” Tectonics, Vol. 26, 2007. https://doi.org/10.1029/2006TC002083

[5] W. Swe, “A Strike-slip faulting in central belt of Burma [abstract],” In: N.S. Haile, ed., Regional Conference on the Geology of Southeast Asia, Kuala Lumpur. Annex to Geological Society of Malaysia Newsletter, Vol. 34, p. 59, 1972.

[6] M.E. Barley, A.L. Pickard, K. Zaw, P. Rak, and M.G. Doyle, "Jurassic to Miocene magmatism and metamorphism in the Mogok metamorphic belt and the India-Eurasia collision in Myanmar,” Tectonics, Vol. 22, No. 3, pp. 1-14, 2003.

[7] A.H.G. Mitchell, "Guides to metal provinces in the Central Himalaya collision belt; the value of regional stratigraphic correlations and tectonic analogies," Memoir of the Geological Society of China, Vol. 3, pp. 167-194, 1979.

[8] I. Metcalfe, "Late Palaeozoic and Mesozoic tectonic and palaeogeographical evolution of SE Asia,” Geological Society, London, Special Publications, Vol. 315, No. 1, pp. 7-23, 2009.

[9] F. Bender, Geology of Burma, Gebrüder Borntraeger, Berlin and Stuttgart, Germany, 1983.

[10] M. Thein, and S. Win, "The metamorphic petrology, structures and mineral resources of the Shantaung-U-Thandawmywet Range, Kyaukse district,” Burma Research Congress, Vol. 3, No. 3, pp. 487-514, 1969.

[11] G. Bertrand, C. Rangin, H. Maluski, and H. Bellon, "Diachronous cooling along the Mogok Metamorphic Belt ( Shan Scarp , Myanmar ): The trace of the northward migration of Diachronous cooling along the Mogok Metamorphic Belt,” Journal of Asian Earth Sciences, No. June 2017, pp. 649-659, 2001.

[12] M.L. Thein, O. Myint, S. Kyi, and H.N. Win, "Geology and stratigraphy of the metamorphosed early Paleozoic rocks of the Mogok- Thabeikkyin- Singu- Madaya Area,” Yangon, 1990. 
[13] S.F. Simmons, and B.W. Christenson, "Origins of calcite in a boiling geothermal system,” American Journal of Science, Vol. 294, No. 3. pp. 361-400, 1994.

[14] A.M. Evans, An Introduction to Ore Geology, $2^{\text {nd }}$ Edition, Blackwell, Oxford, 1987.

[15] R.J. Bodnar, "Revised equation and table for determining the freezing point depression of H2O-NaCl solutions,” Geochimica et Cosmochimica Acta, Vol. 57, No. 3, pp. 683684, 1993.

[16] D. Moncada, and R.J. Bodnar, "Gangue mineral textures and fluid inclusion characteristics of the Santa Margarita Vein in the Guanajuato Mining District, Mexico," Central European Journal of Geosciences, Vol. 4, No. 2, pp. 300-309, 2012.

[17] J.J. Wilkinson, "Fluid inclusions in hydrothermal ore deposits," Lithos, Vol. 55, pp. 229-272, 2001.

[18] E. Roedder, "Fluid Inclusions,” Mineralogical Society of America, Reviews in Mineralogy, Vol. 12, No. Reviews in Mineralogy, p. 644, 1984.

[19] J.R. Curray, “Tectonics and history of the Andaman Sea region," Journal of Asian Earth Sciences, Vol. 25, No. 1, pp. 187-232, 2005.

[20] A.G. Reyes, "Petrology of Philippine geothermal systems and the application of alteration mineralogy to their assessment," Journal of Volcanology and Geothermal Research, Vol. 43, No. 1-4, pp. 279-309, 1990.

[21] D. Moncada, S. Mutchler, A. Nieto, T.J. Reynolds, J.D. Rimstidt, and R.J. Bodnar, "Mineral textures and fluid inclusion petrography of the epithermal Ag-Au deposits at Guanajuato, Mexico: Application to exploration,” Journal of Geochemical Exploration, Vol. 114, pp. 20-35, 2012.

[22] S.F. Simmons, and B. W. Christenson, "Origins of calcite in a boiling geothermal system,” American Journal of Science, Vol. 294, pp. 361-400, 1994.

[23] S.F. Simmons, and P.R.L. Browne, "Hydrothermal Minerals and Precious Metals in the Broadlands-Ohaaki Geothermal System: Implications for understanding lowsulfidation epithermal environments,” Economic Geology, Vol. 95, No. 5, p. 971, 2000 . 